\title{
OBRAZOVANJE BIBLIOTEKARA \\ U BOSNI I HERCEGOVINI ${ }^{1}$
}

\author{
EDUCATION OF LIBRARIANS \\ IN BOSNIA AND HERZEGOVINA
}

\section{Lejla Hajdarpašić}

Filozofski fakultet Univerzitet u Sarajevu

Katedra za informacione nauke

lejla.hajdarpasic@ff.unsa.ba

Senada Dizdar

Filozofski fakultet Univerzitet u Sarajevu

Katedra za informacione nauke

senada.dizdar@ff.unsa.ba

\section{Džejla Khattab}

Filozofski fakultet Univerzitet u Sarajevu

Katedra za informacione nauke

dzejla.khattab@ff.unsa.ba

UDK / UDC: 023.5:37.013.31(497.6)

Pregledni rad / Review paper

Primljeno / Received: 9. 6. 2021.

Prihvaćeno / Accepted: 10. 10. 2021.

\section{Sažetak}

Cilj. Cilj rada je predstaviti historijski pregled formalnog obrazovanja bibliotekara u Bosni i Hercegovini, kao dijela njegove profesionalizacije, koji je u bosanskohercegovačkom kontekstu neophodno sagledati u okviru vrlo specifičnih historijskih i društveno-ekonomskih odnosa, te relativno kasne pojave formalnog obrazovanja bibliotekara u odnosu na svjetske prakse.

Rad je napisan na bosanskom jeziku.

Vjesnik bibliotekara Hrvatske 64, 2(2021), 165-189

ISSN 0507-1925 
Metodologija. Metodološki pristup temi ogleda se u istraživanju literature vezane uz razvoj obrazovanja bibliotekara u Bosni i Hercegovini i sintezi dosadašnjih istraživanja.

Rezultati. Uvidom u relevantnu naučnu i stručnu literaturu uočeno je da je profesionalizacija bibliotekarstva složen proces koji se oslanja na opis poslova, zakonsku regulativu, definiranje kompetencija neophodnih za obrazovanje bibliotekara i različite oblike formalnog i neformalnog obrazovanja.

Vrijednost. Rad je prilog istraživanju formalnog obrazovanja bibliotekara u Bosni i Hercegovini u smislu profesionalizacije te djelatnosti. Analizom je utvrđeno da je potrebno dodatno istražiti austrougarski period, $\mathrm{u}$ vezi s kojim je evidentan niz nepoznanica o edukaciji bibliotekara i načinima na koji su sticali bibliotečka znanja.

Ključne riječi: bibliotekarstvo, Bosna i Hercegovina, obrazovanje bibliotekara

\section{Abstract}

Purpose: The aim of this paper is to present a historical overview of the formal education of librarians in Bosnia and Herzegovina, as part of its professionalization, which in the context of Bosnia and Herzegovina must be seen in the context of very specific historical and socio-economic relations and the relatively late establishment of formal education of librarians compared to world practices.

Methodology: The methodological approach to the topic is reflected in the research of literature related to the development of education of librarians in Bosnia and Herzegovina and the synthesis of previous research.

Results: An insight into the relevant scientific and professional literature shows that the professionalization of librarianship is a complex process that relies on job descriptions, legislation, defining competencies necessary for the education of librarians and various forms of formal and non-formal education.

Value: The paper is a contribution to the research of formal education of librarians in Bosnia and Herzegovina in terms of its professionalization. The analysis has shown that it is necessary to further investigate the Austro-Hungarian period, which has evidently revealed a number of undefined issues about the education of librarians and the ways in which the librarianship knowledge was acquired.

Keywords: Bosnia and Herzegovina, librarian education, librarianship

\section{Uvod}

Historijski razvoj bibliotekarstva prati nekoliko pokazatelja koji ga utemeljuju kao profesiju. Najčešće se profesionalizacija djelatnosti, pa i bibliotekarstva, veže 
za postojanje pravila i opisa poslova te djelatnosti, zatim definiranja kompetencija djelatnika neophodnih za obavljanje tih poslova, postojanje glasila i literature, do postojanja različitih oblika obrazovanja, postojanja društava koja kontroliraju profesionalno ponašanje svojih članova, stepena razvijenosti profesionalne etike. Kod mnogih profesija paralelno se razvijaju vlastita profesionalna udruženja, specifično profesionalno obrazovanje i razvija profesionalna etika. Sama profesija ne nastaje odjednom i mnogo je faktora koji utiču na profesionalizaciju djelatnosti. ${ }^{2}$

Bosanskohercegovačko bibliotekarstvo u svojim specifičnim historijskim, političkim i ekonomskim uslovima prošlo je kroz sve te faze profesionalizacije bibliotekarstva, što svjedoči i veliki broj tekstova koji se bave tom tematikom i koji prate sve mijene razvoja bibliotekarstva. Unutar tog korpusa zastupljeni su i tekstovi koji su obrađivali i teme formalnog i neformalnog obrazovanja bibliotekara, gdje veliki broj čine tekstovi unutar monografskih publikacija i vezani su za historijski razvoj djelatnosti (Bašović, Hadžiosmanović, Kalender, Memija, Kalender, Lavić, Čeliković). Nadalje, drugu grupu čine tekstovi/izvještaji o održavanju raznih vrsta kurseva i seminara za bibliotekare te treću grupu tekstovi koji tematiziraju obrazovanje bibliotekara u Bosni i Hercegovini u formi članaka u časopisima i zbornicima radova (Mihaliček, Leota, Rešidbegović, Rašidović, Dizdar, Maksimović i dr.). ${ }^{3}$

2 Usp. Švenda-Radeljak, K. Počeci razvoja knjižnične profesije u Hrvatskoj od 1875-1918. godine. Zagreb: Pravni fakultet, 2018. Str. 5-10.

3 Izvor za istraživanje teme o obrazovanju bibliotekara pružaju: Bibliografija Biltena Društva bibliotekara BiH i Narodne biblioteke NR BiH i časopisa Bibliotekarstvo: 1952-2001. / izradile N. Grebović-Lendo i suradnici. Sarajevo: Društvo bibliotekara Federacije Bosne i Hercegovine, 2016. Također, povijesni razvoj biblioteka i bibliotekarstva i obrazovanja bibliotekara u BiH dat je u monografijama: Bašović, Lj. Biblioteke i bibliotekarstvo u Bosni i Hercegovini 1918-1945. Sarajevo: Veselin Masleša, 1986.; Bašović, Lj. Biblioteke i bibliotekarstvo u Bosni i Hercegovini 1945-1975. Sarajevo: Svjetlost, 1977.; Hadžiosmanović, L. Biblioteke u Bosni i Hercegovini 1878-1918. Sarajevo: Veselin Masleša, 1980.; Kaleder, F. Radničke biblioteke i čitaonice u Bosni i Hercegovini do 1941. godine. Sarajevo: Društvo bibliotekara Bosne i Hercegovine, 1998.; Memija, E. Od slike do knjige: Iz historije pisma, knjige, štampe i biblioteke. Sarajevo: Nacionalna i univerzitetska biblioteka BiH, 2007.; Celiković, S. Islamske biblioteke u Bosni i Hercegovini 1878-2010. Tuzla: Specijalna biblioteka „Behram-beg“, 2014.; Čeliković, S. Biblioteke i bibliotekarstvo u Bosni i Hercegovini od 1975. do 2010. godine. Sarajevo: Filozofski fakultet, 2018.; Lavić, O. Biblioteke u BiH za vrijeme osmanske uprave: Magistarski rad. Sarajevo: Fakultet islamskih nauka Univerziteta u Sarajevu, 2013. Radovi u časopisima o obrazovanju bibliotekara: Mihaliček, M. Školovanje knjižničara u Bosni i Hercegovini. // Bibliotekarstvo 34(1987), str. 46-49; Mihaliček, M. Obrazovanje knjižničara u školama srednjeg usmjerenog obrazovanja u Bosni i Hercegovini. // Bibliotekarstvo 34(1982), str. 99-100; Leota, A. Kadrovi u bibliotečko-informacionoj djelatnosti Bosne i Hercegovine i njihovo obrazovanje. // Bibliotekarstvo 34(1988), str. 16-19.; Leota, A. Bibliotečki radnici Bosne i Hercegovine i zahtjevi savremenog društva. // Bibliotekarstvo 34(1988), str. 35-39.; Dizdar, S. Obrazovanje bibliotekara za društvo znanja. // XXII. Proljetna škola školskih knjižničara Republike Hrvatske. Školska knjižnica i slobodno vrijeme učenika: Zbornik radova. / urednica B. Šušnjić. Zagreb: Agencija za odgoj i obrazovanje, 2010. Str. 81-91.; Dizdar, S. Bolonjski proces i studij bibliotekarstva. // II. savjetovanje visokog obrazovanja: Primjena Bolonjskih principa na Univerzitetu u Sarajevu. Sarajevo: Univerzitet u 
Problem obrazovanja bibliotekara u Bosni i Hercegovini nije moguće razumijevati bez historijskog, društveno-ekonomskog i političkog okvira koji je uslovljavao načine i oblike obrazovanja. Zbog toga je namjera ovoga rada istražiti i predstaviti razvoj obrazovanja bibliotekara u okviru historijskih etapa, počevši od osmanskog perioda, do postdejtonske Bosne i Hercegovine, mapirajući tekstove koji su dali doprinos razumijevanju te problematike. Tek je iz te perspektive moguće razumjeti zašto se osamdeset godina nakon osnivanja prvih bibliotečkih škola u SAD-u (1887.) i Njemačkoj (1886.), javlja formalno obrazovanje bibliotekara u Bosni i Hercegovini. Naime, formalno školovanje bibliotekara prvi put se organizira u 19 st., i to gotovo istodobno u Njemačkoj i SAD-u. Godine 1886. Karl Dziatzko (1842. - 1903.) imenovan je profesorom bibliotekarstva na Sveučilištu u Göttingenu, a 1887. Melvil Dewey (1851. - 1931.) osniva prvu bibliotekarsku školu School of Library Economy na Columbia College-u u New Yorku ${ }^{4}$. Nakon toga slijedi otvaranje velikog broja škola i u SAD-u i Europi. ${ }^{5}$ Pri tome ne treba zaboraviti da je većina današnjih studija u Europi utemeljena $u$ šezdesetim godinama prošlog stoljeća. ${ }^{6}$

\section{Profesionalizacija bibliotekarstva u BiH od osmanskog perioda do 1945. godine}

\subsection{Osmanski period}

Početke bibliotečke djelatnost u Bosni i Hercegovini moguće je pratiti od osmanskog perioda jer nema nikakvih indicija da su u srednjovjekovnoj Bosni, izuzev manjih ili većih zbirki knjiga, bile organizirane i biblioteke. Prve veće zbirke knjiga vezane su uz vjerske zajednice i organizirane su pri vjerskim ustanova-

Sarajevu, 2008. Str. 261-270.; Dizdar, S. Edukacija bibliotekara: Prilagođavanje tradicionalnih programa «novom vremenu» i promijenjenim zadacima. // ICSL Godišnjak međunarodnog susreta bibliotekara. 3, 3(2007), str. 31-45; Rašidović, B. E. Cjeloživotno učenje informacijskih stručnjaka/bibliotekara i informacijska pismenost. // Proaktivne obrazovne institucije: Mjesto cjeloživotnog učenja u digitalnom dobu: Zbornik radova. / uredili S. Dizdar, A. Rešidbegović i B. Sabljaković. Sarajevo: Asocijacija informacijskih stručnjaka - bibliotekara, arhivista i muzeologa, 2015. Str. 45-52. [citirano: 2021-01-10]. Dostupno na: http://bam.ba/images/stories/ Zbornici/zbornik13.pdf; Rašidović, B. E. Bibliotekari/ke osobe bez identiteta?: Zašto vjerujete svom pekaru, mljekaru, apotekaru, a ne vjerujete svom bibliotekaru?. ur. vijeće R. Donia et. al. Sarajevo: Fondacija "Kemal Bakaršić"; University Press, 6/7, (2011), 9-17.

4 Navedeno prema Erl Šafar, M.; T. Lubina, T. Formalno obrazovanje knjižničara: kratki povijesni pregled. // Vjesnik bibliotekara Hrvatske 61, 1(2018), str. 219-239.

5 Tako je, primjerice u Europi prvi studij bibliotekarstva osnovan još davne 1886. u Göttingenu, zatim u Münchenu 1905., a u Londonu 1919. godine. Prema Erl Šafar, M.; T. Lubina, T. Nav. dj., str. 219-239.

${ }^{6}$ Horvat, A. Školovanje knjižničara u svjetlu europskih normi. // Vjesnik bibliotekara Hrvatske 48(2005), str. 6 . 
ma, uz džamije, mektebe, medrese i tekije, te uz crkve, samostane i manastire. U osmanskom periodu uspostavljena su dva karakteristična tipa biblioteka - istočnjačke i zapadne, čiju tipologiju je moguće pratiti i u kasnijim razdobljima. I pored sličnosti, te biblioteke imaju neke specifičnosti u nastajanju, vođenju i organizaciji fondova, što je uslovljavalo i njihov razvoj, slijedom utemeljenja u različitim praksama organiziranja biblioteka na Istoku i Zapadu.

Jedna od važnih razlika ogleda se u tome što su islamske (orijentalne) biblioteke nastajale kao vakuf (zadužbina), izuzev privatnih biblioteka. Institucija vakufa, kao jedne od najznačajnijih tekovina islama, gotovo je nepoznata zapadnom svijetu, koji svoj pandan vakufima ima u zakladnim institucijama, čijim posredstvom se zavještavaju naučno-istraživački instituti, univerziteti, fondacije, zdravstvene, karitativne, religijske i druge ustanove. Pravni dokument kojim se institucionalizira vakuf poznat je pod nazivom vakufnama ili vakfija. U vakufnamama se nalaze dragocjeni podaci o osnivanju biblioteka, spisku poklonjenih knjiga, načinima na koji se biblioteka treba voditi, ali i plaćama bibliotekara, što predstavlja važan vid pravne regulative djelatnosti koja vodi ka njenoj profesionalizaciji. Kao primjer osmanske biblioteke svakako možemo navesti zavještanje biblioteke za džamiju u Skoplju, 1469. godine, vakufnamom Isa-bega Ishakovića, utemeljitelja Sarajeva. Tom bibliotekom udareni su temelji tematskoj podjeli knjiga koja je, s manjim odstupanjima, zadržana naredna tri do četiri stoljeća na bosanskohercegovačkom prostoru. Prije samog popisa knjiga autor ističe da su to referentni i od islamske uleme priznati i provjereni naslovi pogodni za obrazovanje učenika. Vakif je odredio i bibliotekara, odnosno hafizi-kutuba s dnevnom plaćom od tri aspre, što je bilo u nivou imama mesdžida ili mujezina u džamiji. ${ }^{7}$ Vakufname donose podatke o fondovima i njihovim vlasnicima, a fragmentarno se pominju, poimenično navode i opisuje uloga bibliotekara.

Nešto podataka o bibliotekama i bibliotekarima u Sarajevu nalazimo i kod Mula Mutafe Bašeskije u Ljetopisu (1746. - 1804.), gdje među ljude od znanja ubraja i hafiza Mahmuda. ${ }^{8}$ Za hafiza Mula Mahmuda Bašeskija kaže da je bio: „hafiz Kur'ana“ i „hafiz kutbhane“, što, kako objašnjava Filan, znači da je čuvao Kur'an u pamćenju (hafiz) i knjige u biblioteci“. 9

O tome tko su bili ti prvi bibliotekari znamo relativno malo. Neki historičari smatraju da je Gazi Husrev-begova biblioteka imala bibliotekara dosta rano, čak polovinom 17. stoljeća, što je u vezi sa javnošću njene djelatnosti. Mehmed Tahir u djelu Osmanli Müellifleri, govoreći o Husein-efendiji Bosneviju (umro 1644. godine), poznatom i kao Kodža Muerrih, navodi da mu je otac bio hafizi-kutub (bibliotekar) u biblioteci Gazi Husrev-begove džamije. ${ }^{10}$

\footnotetext{
Usp. Lavić, O. Nav.dj., str. 33.

8 Bašeskija, M. M. Ljetopis. Sarajevo: Sarajevo-Publishing, 1997. Str. 187.

9 Filan, K. Sarajevo u Bašeskijino doba. Sarajevo: Connectum, 2014. Str. 96.

10 Usp. Lavić, S. Nav. dj., str. 47.
} 
Moguće je da se da se status i plata bibliotekara vežu uz funkciju javnosti biblioteka. Poznato je da su se u Osmanskom carstvu krajem 17. stoljeća počele osnivati samostalne biblioteke koje su mogli koristili i učenici i građani. Prve javne biblioteke u Bosni i Hercegovini kao samostalne institucije pratimo od 1630. godine osnivanjem biblioteke u Banja Luci, vakufnamom Mevla Husamuddina Bošnjaka. ${ }^{11} \mathrm{Ka}-$ snije su u Sarajevu ${ }^{12}$ osnovane Šehdijina (1757.) i Kantamirijina biblioteka (1774.). ${ }^{13}$ U javnim bibliotekama, ili onim koje su imale mogućnost posudbe knjiga, radili su bibliotekari uz naknadu. Uz određenje plaće bibliotekaru nije bio rijedak slučaj da se opiše i kakav to treba biti djelatnik koji vodi brigu o biblioteci. Tako pomenuti Husamuddin Bošnjak u svojoj zavještajnici određuje mjesto plaćenog bibliotekara, u čiju je dužnost spadalo „da čuva časne knjige i da ih štiti od pogleda onih što su ograničena uma, te da ih ne izdaje izvan grada." Dalje zahtijeva da se od mutevelijine ${ }^{14}$ plaće naplati svaka šteta učinjena knjizi, ili njen gubitak. ${ }^{15}$

Profesionalizacija bibliotekarstva počet će kasnije, tek početkom 19. stoljeća u Osmanskom carstvu, tačnije od 1839. godine u vremenu Tanzimata (razdoblje društveno-političkih reformi od 1839. do 1856. godine) kada dolazi i do promjena u organiziranju rada biblioteka. Reforma bibliotekarstva ogleda se u dijelu bibliotečkog poslovanja, jer se počinju pisati inventarne knjige, izrađivati kataloški listići, te vršiti podjela knjiga prema temama i podgrupama, a sve s ciljem olakšavanja posla bibliotekarima, boljeg čuvanja i zaštite knjige, te povećanja nivoa usluživanja korisnika. Tada se i u islamskim bibliotekama u Bosni i Hercegovini javljaju prvi popisi knjiga, što korespondira i sa prvim popisima knjiga u katoličkim i pravoslavnim bibliotekama na ovim prostorima. Važan datum u profesionalizaciji bibliotekarstva je osamostaljenje Gazi Husrev-begove biblioteke 1864. godine, kada se zvanično u ovoj Biblioteci uspostavlja profesija bibliotekara, te su od tog vremena poznati svi njeni bibliotekari. Prvi imenovani bibliotekar ( $\mathrm{tj}$. hafizi-kutub) bio je hafiz Abdulah Ajni ef. Hasagić, a drugi je bio Salih Sidki-ef. Hadžihuseinović Muvekkit. ${ }^{16}$

11 Mujezinović, M.; M. Traljić. Vakufnama iz 1630. godine o osnivanju biblioteke Mevla Husamuddina Bošnjaka u Banjoj Luci. // Glasnik islamske vjerske zajednice 40, 1(1977), str. 29.

12 Za vrijeme osmanske vladavine u Bosni i Hercegovini (1463.-1878.) Sarajevo je imalo tri javne orijentalne biblioteke i to: Gazi Husrev-begova (osnovana 1537.) nastala uz medresu, ali je bila i javna biblioteka; Osman Šehdijina (osnovana 1757, porušena 1910, a njen fond je priključen Gazi Husrev-begovoj biblioteci 1914.) i Abdulah efendije Kantamirije (osnovana 1774, a porušena 1897. godine).

13 Fajić, Z. Biblioteka Abdullah efendije Kantamirije. // Anali Gazi Husrev-Begove biblioteke 8(1987), str. 13-14, 15-36. [citirano: 2021-04-18]. Dostupno na https://anali-ghb.com/index. $\mathrm{php} / \mathrm{aghb} /$ article/view/502.

14 Osoba određena kao upravitelj vakufa.

15 Ždralović, M. Bosansko-hercegovački prepisivači djela u arabičkim rukopisima, Knj. I. Sarajevo: Svjetlost, 1988, str. 32.

16 Popis bibliotekara Gazi Husrev-begove biblioteke nakon osamostaljena 1864. godine vidi kod Ćeliković, S. Islamske biblioteke u Bosni i Hercegovini 1878-2010. Tuzla: Specijalna biblioteka „Behram-beg“, 2014, str. 59. 
Već u 19. stoljeću i u drugim vjerskim zajednicama javljaju se poimenično bibliotekari. O životu katolika važan izvor informacija su šematizmi (službeni popis, kratak pregled života jedne zajednice) iz kojih, primjerice, saznajemo da je u Franjevačkom samostanu sv. Petra i Pavla na Gorici u Livnu prvi bibliotekar imenovan 1864. godine, a bio je to fra Grgo Lozić (R. P. Gregorius Lozić). ${ }^{17}$

\subsection{U civilizacijskom krugu Austro-ugarske monarhije}

Nakon četiri i po stoljeća neprekidnog života u islamskom kulturno-civilizacijskom i duhovnom ozračju Osmanske države, Bosna i Hercegovina se odlukom Berlinskog kongresa i Carigradskom konvencijom 1878. godine našla u krišćanskom kulturnom civilizacijskom krugu Austro-ugarske monarhije. Specifični uslovi pod kojima je Bosna i Hercegovina pripojena Monarhiji su definirali i njen poseban status, kao corpus separatum, sve do njene aneksije 1908. godine. To znači da stanovnici Bosne i Hercegovine nisu pravno bili ni austrijski niti ugarski državljani, nego su tretirani kao bosanskohercegovački zemaljski pripadnici. Kao corpus separatum unutar Monarhije, Bosna, međutim, nije bila ravnopravna sa njene druge dvije države. Bosna i Hercegovina nije imala nikakvih samoupravnih prava, niti je mogla učestvovati u tzv. zajedničkim poslovima u Monarhiji, pa se u političkom pogledu nalazila u potpuno zavisnom položaju u odnosu na Austriju i Ugarsku. Ta zamršena državna organizacija odrazila se i na obrazovni sistem unutar Carstva te posljedično tome i na organizaciju biblioteka i njihovo poslovanje.

Stoga, zakoni o razvoju bibliotekarstva koji su primjerice važili u Hrvatskoj (kao dijelu Austro-Ugarske Monarhije), nisu se u istom kapacitetu odnosili i na Bosnu i Hercegovinu. Moderno visokoškolsko bibliotekarstvo u Austro-Ugarskoj utemeljila je svojim reformama još Marija Terezija u 18. stoljeću, koje je vodilo sekularizaciji škola i osnivanju sveučilišta, a od biblioteka zahtijevala je reformu zakonske regulative poslovanja biblioteka. Ustroj i razvoj biblioteka bio je u potpunosti reguliran državnim propisima. Od svih tih propisa najznačajnije su Instrukcije iz 1825. godine koje su omogućavale uređenje visokoškolskih biblioteka u Monarhiji. ${ }^{18}$

S obzirom da se bosanskohercegovački obrazovni sistem u mnogome razlikovao od austrougarskog, primjena takve organizacije biblioteka nije bila moguća. U vrijeme Austro-Ugarske, školstvo je bilo podijeljeno na konfesionalno, narodno ili državno te privatno. Škole su bile muške i ženske, a negdje i mješovite. Škole

17 Schematismus almae Missionariae provinciae Bosnae Argentinae ordinis fratrum Minorum observantium: pro anno 1864. Budae: Typis Martini Bagô, 1864., str. 63. U tom Šematizmu pominju se i bibliotekari u samostanu u Fojnici, R. P. Augustinus Dembić (str. 39) i u samostanu Guča Gora, R. P. Antonius Gutić (str.78).

18 Švenda-Radeljak, K. Obrazovanje i status kjižničara u Hrvatskoj do uvođenja studija bibliotekarstva. Zagreb: Pravni fakultet, 2018. Str. 16. 
su imale svoje priručne biblioteke, a njihova organizacija i propisi su se odnosili najviše na nabavku i uređenje knjižnog fonda. ${ }^{19}$

Novina je bila pojava Biblioteke Zemaljskog muzeja, prve naučne biblioteke, osnovane 1884. godine.$^{20} \mathrm{O}$ uređenje biblioteke i djelokrugu rada možemo saznati iz Provisorisches Statut fur das bosnischherzegovinische Ladnesmuseum in Sarajevo, objavljenom u izdanju Zemaljske štamparije 1894. godine. U Provizornom statutu za bosansko-hercegovački Zemaljski muzej u Sarajevu navodi se da: „Muzej posjeduje svoju posebno postavljenu i inventariziranu biblioteku a da o njenom vođenju brine direktor". Nažalost, u tom Statutu nema podataka o bibliotečkim stručnjacima, koji su uz direktora bili zaduženi za rad u Biblioteci. Ipak se zna, na osnovu ranijih istraživanja, da su u njoj radili eminentni stručnjaci tog vremena. ${ }^{21} \mathrm{U}$ prvim danima rada Biblioteke Zemaljskog muzeja brigu o njoj preuzeli su, na volonterskoj osnovi, uz svoje osnovne referate iz znanstvenih disciplina koje su obrađivali, prvi stručnjaci Zemaljskog muzeja. U kalendaru Bošnjak (1883. 1918. godine), u poglavlju Kalendara pod naslovom Šematizmi svijeh oblasti u Bosni i Hercegovini, od 1889. godine, pojavljuju se podaci o prvim djelatnicima biblioteke: dr. Konstantin Hormann, dr. Ćiro Truhelka, Othmar Reiser, Franjo Fiala, Vaclav Radimsky. ${ }^{22}$

U časopisima Školski vjesnik i Školski glasnik nailazimo na neke podatke o razvoju biblioteka u tom periodu. ${ }^{23}$ Zadaci koje bibliotekar treba da obavlja u biblioteci dati su u Uputama za uređenje i vođenje zavodskih biblioteka u srednjim i osnovnim školama, koju je izdala vlast 1916. godine. Rad nastavnika bibliotekara

19 Papić, M. Školstvo u BiH u vrijeme austrougarske okupacije (1878.-1918). Sarajevo: Veselin Masleša, 1972. Str. 64.

20 U sklopu Zemljskog muzeja djelovao je Institut za istraživanje Balkana (1904.-1918.) u kojem je djelovala i biblioteka. Ta biblioteka je važna zbog orijentalne zbirke rukopisa koji je prikupila i pojave prvih bibliografa koji se institucionalno bave tim poslom. Na bibliografskim istraživanjima radili su: Ferdinand Velc (1864.-1920.), Hamdija Kreševljaković (1888. - 1959.), fra Julijan Jelenić (1877. - 1931.) i dr. Pavao Mitrović (1887.-1956.). Prema: Bakaršić, K. Fragmenti kulturne historije Bosne i Hercegovine. Sarajevo: Magistrat, 2005. Str. 49.

21 Lalević, O.; A. Dautović. Biblioteka Zemaljskog muzeja Bosne i Hercegovine do 1897. godine. // Informatica museologica 29, 1-2(1998), str. 75.

22 Konstantin (Kosta) Hörmann (1850.-1921.) kulturni radnik, od 1878. visoki činovnik austrougarske vlade u Bosni i Hercegovini. Prvi ravnatelj i organizator Zemaljskoga muzeja (1888.), uređivao (od 1889. godine) časopis Glasnik Zemaljskog muzeja za Bosnu i Hercegovinu. Pokrenuo je značajni književni časopis Nada (1895.), koji je uređivao Silvije Strahimir Kranjčević; Ćiro Truhelka (1865.-1942.), bio je hrvatski arheolog, povjesničar i povjesničar umjetnosti; Othmar Reiser (1861.-1936.) pionir balkanske ornitologije; Fiala Franjo (1861.-1898.), bosanski arheolog češkog podrijetla; Vaclav Radimsky pripada prvoj generaciji stručnjaka Zemaljskog muzeja $\mathrm{BiH}$. Iako je, kao geolog, radio na sređivanju zbirki minerala i geološkog materijala, ostao je trajno upamćen po doprinosu u istraživanju arheoloških, prahistorijskih i antičkih lokaliteta u $\mathrm{BiH}$.

23 Školski vjesnik (1894.-1923.) je prvi pedagoški list, u austougarskom periodu koji izdaje Zemaljska vlada za BiH. Školski glasnik (1910.-1923.) je nastao kao školski službeni list Zemaljska vlada za Bosnu i Hercegovinu. 
se sastojao u izdavanju i primanju knjiga u fondu za nastavnike, a u đačkoj biblioteci vodio se inventar knjiga, vršena je revizija, potvrđivali su se računi prilikom nabavke i vodila briga o uvezivanju i naknadnoj šteti za izgubljenom knjigom. ${ }^{24}$

U austrougarskom periodu i dalje se profesionalizacija bibliotekarstva odvijala jasnijim definiranjem upravljanja zbirkom i nabavkom građe, te konstituiranjem novih vrsta biblioteka, osobito školskih biblioteka, koje su u početku bile osnova za dalji razvoj bibliotekarstva, te osnivanje Biblioteke Zemaljskog muzeja, prve naučne biblioteke u Bosni i Hercegovini.

\subsection{Kraljevina Srba, Hrvata i Slovenaca / Kraljevina Jugoslavija}

Versajskim mirom 1918. godine okončan je Prvi svjetski rat, a Bosna i Hercegovina se našla u okviru nove države Srba, Hrvata i Slovenaca koja vrlo brzo dobija ime Kraljevina Jugoslavija. Jedan od problema bio je prekid zakonske regulative i nedorečenost novih zakona. Tako su mnoge profesije, među kojima je i bibliotekarstvo, ostale bez zakonskog okvira. Organizacija i stručno uređenje biblioteka još su bili u procesu izgradnje i traganja za svjetskim uzorima, što se ogledalo, prije svega, u dosta šarolikoj i neujednačenoj praksi, počev od smještaja i signiranja knjižne građe, sve do izrade kataloga i napora da se ovi poslovi podignu na kvalitetniji stručni nivo „držeći se općih načela dobro uređenih biblioteka." ${ }^{25}$

U cilju unapređenja djelatnosti u tom periodu javljaju se i prve štampane upute o uređenju biblioteka. Jedan od najstarijih tekstova o uređenju biblioteka je rad poznatog bibliografa Đorđa Pejanovića Kratka uputstva za osnivanje, uređenje i rukovanje narodnih javnih knjižnica koja su štampana u Sarajevu, 1920. god. ${ }^{26}$

Ovaj period, kako navodi Bašović, karakterizira važan događaj, a to je osnivanje Društva jugoslovenskih knjižničara 1931. godine u Zagrebu, čiji su inicijatori i članovi iznijeli u javnost većinu najvažnijih problema oko položaja i razvoja bibliotečke djelatnosti. Važna aktivnost tog društva je bilo i donošenje teksta nacrta Zakona o bibliotekama. Nacrt Zakona se oslanjao na tadašnje progresivne bibliotečke zakone u pojedinim zemljama Europe i svijeta, podvrgavajući kritici jugoslovenske propise kojima se ta problematika samo djelimično ili nikako rješavala. ${ }^{27} \mathrm{Za}$ ovu temu bitno je napomenuti da je u Nacrtu istaknuto da je potrebna i konsolidacija jugoslovenskog bibliotekarstva na čisto profesionalnoj osnovi, jer se očekivalo rješenje problema integralne profesionalizacije i bibliotekarstva i bibliotečkih zvanja, od najnižih do najviših položaja.

\footnotetext{
24 Hadžiosmanović, L. Nav.dj., str. 125.

25 Bašović, Lj. Nav. dj., str. 16.

26 Pejanović, Đ. Kratka uputstva za osnivanje, uređenje i rukovanje narodnih javnih knjižnica. Sarajevo: Društvo prosvjeta, 1920.

27 Bašović, Lj. Nav dj., 1986. Str. 18.
} 
Nastojanje da se donese Zakon o bibliotekama nije urodio plodom ni nakon Rezolucije koju je donio Drugi kongres knjižničara, održan u Beogradu 1937. godine, te ce se tek dvije decenije nakon toga donijeti prvi zakon o bibliotekarstvu. Ni u tom, kao ni u dotadašnjim periodima, nije bilo formalnog obrazovanja bibliotekara.

\section{Formalno obrazovanje bibliotekara u Bosni i Hercegovini nakon Drugog svjetskog rata}

Nakon Drugog svjetskog rata Bosna i Hercegovina je u sastavu Socijalističke Federativne Republike Jugoslavije i to je najznačajniji period u profesionalizaciji bosanskohercegovačkog bibliotekarstva. Permanentno obrazovanje bibliotekara za sve vrste biblioteka javlja se nakon Drugog svjetskog rata i vezano je za osnivanje Narodne biblioteke Socijalističke Republike Bosne i Hercegovine 1945. godine. Postepeno, broj profesionalnih bibliotekara raste i javlja se potreba za osnivanjem jedne strukovne organizacije ili udruženja, kako bi se taj kadar okupio i stručno usavršavao. Društvo bibliotekara Bosne i Hercegovine osnovano je 18. septembra 1949. godine u sklopu Ministarstva prosvjete Bosne i Hercegovine, a godinu dana prije, januara 1948. godine, pri Odjeljenju za narodno prosvjećivanje, osnovan je Referat za biblioteke i čitaonice, koji aktivno djeluje od 1949. godine. Referat se odmah pobrinuo o stručnom usavršavanju bibliotekara te je već u februaru (1. 2. - 6. 2.) održan kurs za rukovodioce sreskih i gradskih narodnih biblioteka na Ilidži kod Sarajeva.

Uz kurseve koji su se održavali u Bosni i Hercegovini u tom periodu, stručna bibliotečka znanja bibliotečki djelatnici su sticali u većim bibliotekama u Zagrebu, Beogradu i Ljubljani. Nakon toga, u periodu 1946. - 1952. godine, samostalno su organizovali kurseve i stručne obuke, u početku prvo za rukovodioce biblioteka, a zatim i za sve ostale bibliotečke radnike. Brigu o permanentnom i formalnom obrazovanju bibliotečkog kadra preuzela je služba koja se, kada je osnovana 1952. godine, nazivala Bibliotečki centar. ${ }^{28}$

Prvi tekstovi o toj problematici javljaju se već početkom pedesetih godina u časopisu Bibliotekarstvo koji od 1955. godine daje popis bibliotekara i knjižničara koji su položili stručni ispit, što je dugo vremena bio jedini oblik provjere stručnih znanja u ovoj djelatnosti. ${ }^{29}$

28 Nacionalna i univerzitetska biblioteka Bosne i Hercegovine: 1945-2005: 60 godina u misiji kulture, obrazovanja i nauke. Sarajevo: NUBBiH, 2005, str. 27-28. Vidi i Lj. Bašović. Biblioteke i bibliotekarstvo u Bosni i Hercegovini 1945-1975. Sarajevo: Svjetlost, 1977. Str. 21.

29 Bibliografija Biltena Društva bibliotekara BiH i Narodne biblioteke NR BiH i časopisa Bibliotekarstvo: 1952.-2001. Izradile N. Grebović-Lendo i suradnici. Sarajevo: Društvo bibliotekara Federacije Bosne i Hercegovine, 2016. 
U časopisu Bibliotekarstvo, najraniji tekst o problemima školovanja bibliotekara dao je Zlatko Gašparović, u članku Problemi školovanja bibliotečkih kadrova u kome daje kritičku analizu obrazovanja bibliotekara na nivou bivše Jugoslavije, istina, sa posebnim osvrtom na školovanje bibliotekara u Hrvatskoj. Još tada Gašparović ističe da su veliki problemi u metodi nastave, te navodi da:

„Bibliotekarska nastava uz već priznate metode kod standardnih tipova nastave na visokim školama treba i tehničkih metoda koje se inače ne primjenjuju kod ostalih studija. Tim tehničkim metodama želi se studentu dati praktično znanje za rad iz prve ruke. Zbog toga postoji u neku ruku sukob između ,praktičnog i teorijskog gledišta“.

Gašparović ipak smatra da je za obrazovanje bibliotekara od velike važnosti teorijsko znanje da bi mogli obavljati djelatnost koja pruža mogućnost: "da adaptira prihvaćene metode i iznađe shodne postupke i pogodnu organizaciju s obzirom na promjene u društvenim i odgojnim potrebama jedne društvene zajednice. ${ }^{\text {“30 }}$

Nakon toga počinje i formalno obrazovanje bibliotekara u visokoškolskim institucijama što se poklapa sa formalnim visokoškolskim obrazovanjem bibliotekara na prostorima Zapadnog Balkana.

\subsection{Osnivanje studija bibliotekarstva na Filozofskom fakultetu u Sa- rajevu}

Prednost studija bibliotekarstva, u odnosu na studije za obrazovanje drugih informacijskih stručnjaka (npr. arhivista, muzeologa, dokumentalista, informacijskih menadžera) koji su se uspostavljali kasnije, ili su se nudili kao pomoćni studiji (npr. arhivistika uz historijske znanosti), ogleda se u tome što je bibliotekarstvo imalo svoju tradiciju samostalne studijske grupe.

Uspostavljanje sistema redovnog školovanja bibliotečkog kadra u Bosni i Hercegovini može se pratiti od 1957. godine kada je Društvo bibliotekara Bosne i Hercegovine pokrenulo inicijativu da se u Sarajevu osnuje viša bibliotekarska škola ili odsjek za bibliotekarstvo, pri Višoj pedagoškoj školi u Sarajevu. Bilo je i prijedloga da se u završnim razredima učiteljske škole uvede predmet bibliotekarstvo, jer su najčešće učitelji obavljali bibliotečke poslove u školskim bibliotekama. Formalno bibliotečko obrazovanje uvedeno je u Bosni i Hercegovini 1961. godine zalaganjem Društva bibliotekara Bosne i Hercegovine i Bibliotečkog centra Narodne biblioteke Bosne i Hercegovine. To je bila prva Katedra za bibliotekarstvo na Višoj pedagoškoj školi. ${ }^{31}$

30 Gašparović, Z. Problemi školovanja bibliotečkih kadrova. // Bibliotekarstvo 1(1962), str. 8.

31 Nastavni plan i program Katedre obuhvatao je ukupno 18 časova predavanja i 12 časova praktičnog rada u prvom semestru i isto toliko i u drugom semestru. Studij je organiziran kroz nastavne predmete: Osnove bibliotekarstva, Istorija pisma i knjige, Istorija biblioteka, Organizacija 
Katedra je prestala raditi 1969. godine, kada je poslije prerastanja Više pedagoške škole u Pedagošku akademiju odlučeno da se Katedra uklopi u nastavni program visokoškolskih institucija. Već tada je uočeno da je bibliotekarstvo potrebno izučavati na akademskom nivou, a tome je doprinjela potreba usaglašavanja obrazovanja bibliotekara sa svjetskim obrazovnim standardima.

Sedamdesete godine na globalnom planu donose nezapamćen utjecaj tehnologije na sve oblasti života, što je rezultiralo promjenama u načinu proizvodnje i širenja informacija, te razvojem baštinskog sektora u novom tehnološkom okruženju. Bilo je neophodno mijenjati dotadašnje načine rada, ali i obrazovanja kadra za taj sektor. To je zahtijevalo i strateško planiranje razvoja tog sektora, što je za Socijalističku Republiku Bosnu i Hercegovinu značilo i analizu stanja, te izradu strategije za njen daljnji razvoj u tom domenu. Zato je 1970. godine napravljena Analiza stanja u bosanskohercegovačkom bibliotekarstvu (poznata kao Bijela knjiga), koja je imala ključnu ulogu u skretanju pažnje društvene zajednice na probleme bibliotekarstva, a kasnije će se pokazati i veliki utjecaj na daljnji razvoj bibliotekarstva u Bosni i Hercegovini.

Nedugo nakon sprovedene Analize i zaključaka Skupštine Saveza društava bibliotekara Jugoslavije održane na Bledu u jesen 1971. godine, na kojoj je usaglašen cjelovit koncept sistema školovanja bibliotečkog kadra u Jugoslaviji, 1972. godine je na Filozofskom fakultetu u Sarajevu osnovan Odsjek za opštu književnost, scenske umjetnosti i bibliotekarstvo. ${ }^{32}$ Osnivanje Katedre za bibliotekarstvo predstavlja najveću promjenu u obrazovanju bibliotečkog kadra u Bosni i Hercegovini.

Dileme koje su prethodile u osmišljavanju nastavnih planova i programa u bosanskohercegovačkom bibliotekarstvu nastavljaju se i u periodu izrade nastavnih planova i programa za fakultetsko obrazovanje bibliotekara. Sublimaciju svih tih razmišljanja dala je Ljubinka Bašović u tekstu Prilog proučavanju problematike nastavnog plana i programa studija iz oblasti bibliotekarstva u kome navodi: „Otuda sve veća preorjentacija postojećih katedri za bibliotekarstvo u svijetu na katedre za bibliotekarstvo i naučnu informaciju, gdje studenti stiču znanja iz dva pravca bibliotekarstva i informatike“".33 Ovo njeno opredjeljenje da se bibliotekarstvo proučava u okviru informacijskih znanosti sigurno je vezano i za njeno obrazovanje kao svršenice postdiplomskog studija iz bibliotekarstva, dokumentacije i informacijskih znanosti, pri Prirodno-matematičkom fakultetu Sveučilišta u Zagrebu gdje je magistrirala 1968. godine, i uz njene studijske boravke u Rusiji (1970.) i kasnije Sjedinjenim Američkim državama (1977.). ${ }^{34}$

bibliotečkog fonda i katalogizacija, Klasifikacija nauka i bibliotečka klasifikacija, Bibliografija i jugoslovenska izdavačka djelatnost, Rad sa čitaocima i Književnost. Predavači na katedri u periodu od 1961.-1969. godine za bibliotekarstvo bili su: Dobrila Bokan, Seid Prašo, Slavko Simić, Drago Vidović i Zumreta Zahirović. Više o tome vidi Bašović, Lj. Nav. dj. 1977. Str. 24; 52.

32 Bašović, Lj. Nav. dj., 1977, str. 29-30. i str. 42-43.

33 Bašović, Lj. Prilog proučavanju problematike nastavnog plana i programa studija iz oblasti bibliotekarstva. // Bibliotekarstvo 20, 1(1974), str. 25; 29-31.

34 Radulović, Z. Dr Ljubinka Bašović: Bibliotekar i pedagog novog doba. // Glasnik Narodne biblioteke Srbije 4, 1(2002), str. 11-36. 
Prvi Nastavni plan i program (u daljem tekstu NPP) Odsjeka za opštu književnost, scenske umjetnosti i bibliotekarstvo za akademsku 1972./73. godinu koncipiran je tako da se bibliotekarstvo izučavalo kao posebna studijska grupa, u kombinaciji sa opštom književnosti.

U NPP-u za četverogodišnji studij bilo je predviđeno ukupno 15 predmeta, od kojih su neki bili četverosemestralni, dvosemestralni, trosemestralni predmeti. Nastavnih predmeta iz književnosti bilo je pet (Opšta i komparativna književnost I, Opšta i komparativna književnost II, Teorija književnosti, Istorija svjetske drame i pozorišta i Publicistička stilistika), a bibliotekarstvo je imalo pet predmeta (Istorija pisma, knjige i biblioteka, Organizacija biblioteka, Katalogizacija i klasifikacija, Bibliografija i istraživački rad i Teorija informacija). ${ }^{35}$

Revizija Programa urađena je za ak. 1977./78.. godinu, ali NPP za oblast bibliotekarstva nije pretrpio promjene; ni sljedeća revizija programa, koja je urađena za akademsku 1980./81. godinu, nije donijela nove nastavne sadržaje.

Značajnije promjene u sistemu obrazovanja dešavaju se nakon 1988. godine, kada je Statutom Filozofskog fakulteta u Sarajevu omogućeno kombinovanje dvopredmetnih studija, te se bibliotekarstvo počinje studirati kao jedna od grupa u kombinaciji sa ostalim grupama koje se izučavaju na Filozofskom fakultetu (strani jezici, historija, književnost, filozofija, filologija i dr.). Sljedeća novina u obrazovanju bibliotekara javila se 1990. godine kada je NPP-om predviđen novi predmet Informatika. ${ }^{36}$

To je vrijeme kada se počinje obrazovati i srednjoškolski kadar za rad u bibliotekama. Naime, krajem sedamdesetih godina 20. stoljeća u Bosni i Hercegovini se raspravljalo i o pokretanju srednjeg usmjerenog školovanja za zanimanje knjižničar što je urađeno u sklopu reformi obrazovanja poznatog kao usmjereno obrazovanje. ${ }^{37}$ Nakon donošenja Zakona o srednjem usmjerenom obrazovanju (1979. godine) i Nomenklature zanimanja ${ }^{38}$ i u Bosni i Hercegovini započinje redovno školovanje knjižničara. Na osnovu Zakona o srednjem usmjerenom obrazovanju

35 U prvom NPP od samog pokretanja studija uvedeno je izučavanje jednog stranog jezika tokom četiri semestra, Istorija umjetnosti (dva semestra) i opšti predmeti Osnove marksizma (četiri semestra), Osnove narodne odbrane (četiri semestra) i dva semestra fizičke kulture čiji fond časova nije ulazio u ukupan zbir časova. Predviđen je i predmet Publicistička stilistika koji će se realizirati tek 1977. godine sa novim NPP-om. Usp. Nastavni plan i program sa režimom studija. Sarajevo: Filozofski fakultet. Odsjek za opštu književnost i bibliotekarstvo, 1973, str. 1-18.

36 Nastavni plan i program. Sarajevo: Filozofski fakultet. Odsjek za opštu književnost i bibliotekarstvo, 1990. Str. 1.

37 Čeliković, S. Biblioteke i bibliotekarstvo u Bosni i Hercegovini od 1975. do 2010. godine. Tešanj: Planjax komerc, 2019. Str. 68-71.; Usp. i Čaki, P. Predlog sistema školovanja bibliotečkih radnika u SFRJ. // Bibliotekarstvo 14, 1-2(1978), str. 55.

38 U Nomenklaturi zanimanja, između ukupno 917 opisanih zanimanja, u kategoriji 4. kategorije zanimanja i poslova za koje je potrebno četvorogodišnje obrazovanje, zanimanje knjižničar spomenuto je kao jedno od zanimanja u oblasti kulture, struka bibliotekarska. Usp. Nomenklature zanimanja. Sarajevo: Privredna komora BiH, 1980. 
(1979. godine) i spomenute Nomenklature zanimanja koja se stiču u srednjem usmjerenom obrazovanju, zanimanje „knjižničar“ bilo je svrstano u IV kategoriju (složeni poslovi i zadaci, oblast kulture, bibliotekarska struka) za koju je predviđeno četvorogodišnje obrazovanje. ${ }^{39}$

Prva generacija knjižničara u Bosni i Hercegovini upisana je školske 1980./81. godine, bila je najbrojnija jer je obrazovanje knjižničara započelo u šest srednjoškolskih centara u Republici: Sarajevu, Zenici, Mostaru, Banja Luci, Tuzli i Bijeljini. ${ }^{40}$ Krajem školske 1984./85. godine uslijed spajanja nekih struka i smanjivanja broja zanimanja došlo je do manjih izmjena u nastavnim planovima i programima (smanjivanje broja časova praktične nastave i uvođenje novih predmeta), ali je zanimanje knjižničar i dalje zadržano.

Taj oblik obrazovanja nestao je sa reformama koje su nastale u postdejtonskoj Bosni i Hercegovini i više nikada nije ni bilo pomena o njegovom vraćanju u srednjoškolski obrazovni sistem.

\subsubsection{Postdiplomski studij iz bibliotekarstva na Filozofskom fakultetu Sarajevo}

Odjek za opštu književnost i bibliotekarstvo prvi je na prostorima bivše Socijalističke Federativne Republike Jugoslavije pokrenuo znanstveni postdiplomski studij iz bibliotekarstva. To mu je bilo omogućeno Statutom Filozofskog fakulteta Sarajevo koji je još 1972. i 1973. godine predvidio mogućnost pokretanja postdiplomskog studija bibliotekarstva kao i omogućavanje sticanja doktorskog zvanja iz oblasti bibliotečkih nauka. ${ }^{41}$

Prvi postdiplomski studij iz bibliotekarstva pokrenut je u februaru 1985. godine pod nazivom „Inovacije u bibliotekarstvu“ ${ }^{42}$ Prva upisana generacija postdiplomaca brojala je 32 studenta. Zbog iskazanog velikog interesovanja kandidata u novembru 1988. godine ${ }^{43}$ na taj postdiplomski studij primljena je još jedna generacija studenata.

Sedamdesetih i osamdesetih godina 20. stoljeća odbranjene su prve doktorske disertacije iz bibliotečkih nauka u Bosni i Hercegovini, pa i u cijeloj tadašnjoj Jugoslaviji, jer su svoje doktorske disertacije na Odsjeku za opštu književnost i

\footnotetext{
39 Mihaliček, M. Obrazovanje knjižničara u školama srednjeg usmjerenog obrazovanja u Bosni i Hercegovini. // Bibliotekarstvo 28(1982), str. 99-101.

40 Čeliković, S. Nav. dj., str. 71.

${ }^{41}$ Postiplomski studij iz bibliotekarstva"Inovacije u bibliotekarstvu“. Sarajevo: Filozofski fakultet, Odsjek za opštu književnost i bibliotekarstvo, 1985.

${ }^{42} \mathrm{Na}$ prvom postdiplomskom studiju iz bibliotečkih nauka „Inovacije u bibliotekarstvu“ predavali su: dr. Ljubinka Bašović, dr. Ismet Dizdarević, dr. Lamija Hadžiosmanović, dr. Vjekoslava Hunski, dr Vojislav Maksimović, dr. Tvrtko Kulenović, dr. Slavko Leovac, dr. Petar Mandić, dr. Emir Žuljević, Desanka Stamatović, dr. Branko Knežević i dr.

43 Nastavni plan za taj postdiplomski studij bio je identičan sa prethodnim postdiplomskim studijem.
} 
bibliotekarstvo prijavili i odbranili brojni naučni radnici iz Beograda, Skoplja, Cetinja, a kasnije i Zagreba i Rijeke. ${ }^{44}$

Prvi poslijeratni postdiplomski studij iz bibliotekarstva Odsjek je organizovao 2008. godine sa upisanih 30 kandidata. Postdiplomski studij pokrenula je prof. dr. Senada Dizdar sa namjerom da se premosti „obrazovni jaz“ između edukacija koja je osposobljavala bibliotekare za tradicionalne poslove u bibliotekama i novih potreba nametnutih razvojem informacijsko-komunikacijskih tehnologija. U NPP-u tog postdiplomskog studija je navedeno da je on pokrenut da bi se udovoljilo zahtjevima koji se danas postavljaju pred biblioteke i bibliotekarstvo. ${ }^{45} \mathrm{Cilj} \mathrm{je}$ bio izučavanje novih bibliotečkih teorija, uz pomoć kojih je moguće razumijevati promjene u bibliotekarstvu i omogućiti upoznavanje sa savremenim informacijsko-komunikacijskim tehnologijama koje obezbjeđuju relizaciju bibliotečkih zadataka u virtualnom okruženju. ${ }^{46}$

\subsection{Formalno obrazovanje bibliotekara na Filozofskom fakultetu Sa- rajevo u postdejtonskoj Bosni i Hercegovini}

Nakon potpisivanja Dejtonskog sporazuma 1995. godine Bosna i Hercegovina je definirana kao samostalna i suverena država teritorijalno-administrativno podijeljena na dva entiteta (Federacija Bosne i Hercegovine i Republika Srpska) i Brčko distrikt. Cjelokupno gledano u $\mathrm{BiH}$ postoji četrnaest vlada na različitim nivoima vlasti. Svaka od vlada ima svoje ingerencije i nadležnost sa visokim stepenom autonomije. Sve se to naravno reflektira i na oblasti obrazovanja i kulture, gdje je oblast kulture decentralizirano uređena. Ministarstvo civilnih poslova Bosne i Hercegovine nadležno je za utvrđivanje osnovnih principa koordinacije,

44 Do 1992. godine na Odsjeku je odbranjeno 13 disertacija. U toku rata (1992.-1995.) odbranjena je jedna doktorska disertacija, po završetku rata, do 2015. godine, još dvije doktorske disertacije iz bibliotečkih nauka.

45 U NPP-u postdiplomskog studija bibliotekarstva ak. 2008./2009. godine bilo je predviđeno ukupno osam obaveznih predmeta (Historija informacijske kulture u Bosni i Hercegovini, Upravljanje informacijama i znanjem, Digitalne biblioteke (Internet i web tehnologije), Epistemologija informacijskih znanosti, Baze podataka, Biblioteka - pojava, razvoj i značaj, Digitalizacija bibliotečke građe, Sistemi za označavanje i pretraživanje informacija) te četiri izborna predmeta (Metapodaci, Kognitivna psihologija, Bosanskohercegovačka periodika u evropskom kontekstu, Osnove web dizajna). U realizaciji nastave učestvovali su profesori sa Odsjeka za informacijske i komunikacijske znanosti Filozofskog fakultet Sveučilišta u Zagrebu (prof. dr. Jadranka Lasić-Lazić i prof. dr. Vladimir Mateljan), profesori sa Elektrotehničkog fakulteta Univerziteta u Sarajevu (prof. dr. Dženana Đonko, doc. dr. Selma Rizvić, i doc. dr. Tadej Mateljan), te sa Filozofskog fakulteta Univerziteta u Sarajevu (prof. dr. Ugo Vlaisavljevic, doc. dr. Nermin Đapo, prof. dr. Lamija Hadžiosmanović, prof. dr. Emina Memija, doc. dr. Senada Dizdar). Taj postdiplomski studij omogućio je kasnije i izradu dvije doktorske disertacije po predbolonjskom režimu studiranja: Rašidović, B. E. (2015.), Čeliković, S. (2017).

46 Nastavni plan i program postdiplomskog studija iz bibliotekarstva: akademska 2007./2008. godina. Sarajevo: Filozofski fakultet u Sarajevu, 2008. Str. 2. 
usklađivanje planova entitetskih tijela vlasti i definisanje strategije na međunarodnom planu u oblasti kulture. Na nivou entiteta postoje ministarstva nadležna za pitanja kulture i to u Republici Srpskoj Ministarstvo prosvjete i kulture, a u Federaciji Bosne i Hercegovine Ministarstvo kulture i sporta. U Federaciji Bosne i Hercegovine nadležnosti u oblasti kulture dalje su na nivou kantonalnih ministarstava. Brčko distrikt Bosne i Hercegovine ima odjel nadležan za pitanja u oblasti kulture. Na sličan način organizirano je i obrazovanje. Oblast obrazovanja je u potpunoj i nepodijeljenoj nadležnosti entiteta Republika Srpska, deset kantona u Federaciji Bosne i Hercegovine i Brčko distrikt Bosne i Hercegovine imaju svoja ministarstva nadležna za obrazovanje, budžet za obrazovanje, utvrđuju obrazovnu i udžbeničku politiku, kao sva druga prava i obaveze koje proističu iz mandata nadležne obrazovne vlasti odgovorne za organizaciju i funkcioniranje obrazovanja na svom području odgovornosti. Na nivou entiteta Federacija Bosne i Hercegovine, Federalno ministarstvo obrazovanja i nauke ima koordinacijsku ulogu.

Taj pravni i institucionalni okvir omogućio je da se decentralizira obrazovna politika, što je rezultiralo i velikim brojem univerziteta i fakulteta u Bosni i Hercegovini. To je omogućilo da se pojave i nove visokoškolske institucije u kojima se obrazuju bibliotekari. Još jedan važan korak u preobrazbi obrazovnog procesa bio je uspostavljanje bolonjskog režima studija i izrada zakona o visokom obrazovanju, u Republici Srpskoj Zakon o visokom obrazovanju i Federaciji Bosni i Hercegovini Okvirni zakon o visokom obrazovanju. Svaki kanton na osnovu tog zakona donio je svoje zakonske akte o visokom obrazovanju. Donešeni su i prvi poslijeratni zakoni u oblasti bibliotekarstva. U Federaciji Bosne i Hercegovine na snazi je Zakon o bibliotečkoj djelatnosti Republike Bosne i Hercegovine, a u Republici Srpskoj trenutno je na snazi novi zakon, Zakon o bibliotečkoj-informacionoj djelatnosti u Republici Srpskoj. ${ }^{47}$

U tom novom društveno-političkom ozračju cjelokupna obrazovna i kulturna djelatnost ima potpuno novu pravnu i finansijsku regulativu. Obrazovanje bibliotekara u postdejtonskoj Bosni i Hercegovini karakterizira i formalno i neformalno obrazovanje, ali i pojava novih visokoškolskih institucija koje ovako državno-pravno uređenje potiče.

U ratnom periodu obrazovanje bibliotekara na Filozofskom fakultetu Sarajevo bilo je sprovođeno prema NPP-u iz 1992. godine, a u poslijeratnom periodu, u akademskoj 2000./01. godini mijenja se naziv Odsjeka za opštu književnost i

47 Zakon o visokom obrazovanju. // Službeni glasnik RS, br. 73/2010, 104/2011, 84/2012, 108/2013, 44/2015, 90/2016, 5/2017 - odluka US, 31/2018 i 26/2019). [citirano 2020-09-19]. Dostupno na: https://www.paragraf.ba/propisi/republika-srpska/zakon-o-visokom-obrazovanju. html; Okvirni zakon o visokom obrazovanju. // Službeni glasnik BiH, br. 59/07). [citirano: 2020 09-19]. Dostupno na: http://fmpe.edu.ba/images/pdf/101_Okvirni_zakon_o_visokom_obrazovanju_u_Bosni_i_Hercegovini.pdf; Zakon o bibliotečkoj-informacionoj djelatnosti u Republici Srpskoj. // Službeni glasnik Republike srpske 2016. br. 44, god. XXV). [citirano: 2020-08-18]. Dostupno na: http://nub.rs/fileadmin/user_upload/Zakon-o-biblioteckoj__djelatnosti.pdf. 
bibliotekarstvo u Odsjek za komparativnu književnost i bibliotekarstvo, a te akademske godine uvodi se u NPP i novi predmet - Digitalne biblioteke, dok nekoliko predmeta mijenja nazive u odnosu na prijeratni NPP.

\subsection{Bolonjski princip studiranja na Univerzitetu u Sarajevu}

Velike promjene u nastavnim planovima i programima studija bibliotekarstva na Filozofskom fakultetu Sarajevo dešavaju se po prelasku Univerziteta u Sarajevu na bolonjski princip studiranja, 2005. godine. U tom periodu, novi program studija bibliotekarstva rađen je na temelju vlastitih iskustava i po uzoru na tadašnje programe Odsjeka za informacijske znanosti Filozofskog fakulteta u Zagrebu, kao i na preporukama međunarodnih ustanova iz područja bibliotekarstva, informacijskih znanosti, arhivistike i izdavaštava, Smjernica Udruženja za bibliotečko-informacijsku djelatnost Ujedinjenog Kraljevstva (CILIP), te preporuka Europskog vijeća informacijskih i dokumentacijskih udruženja (ECIA, 2005). Od velike pomoći su bila i uputstva Radionice održane u Kopenhagenu pod nazivom Evropske kurikularne refleksije o obrazovanju u bibliotečko-informacijskim naukama (Kopenhagen European Curriculum Reflections on Library and Information Science Education), održane u okviru programa Evropskog udruženja za obrazovanje i istraživanje u bibliotečko-informacijskim naukama (European Association for Library and Information Education and Research, EUCLID), $u$ čijem tekstu su dati preliminarni zaključci vezani za izobrazbu stručnjaka u polju informacijskih znanosti. Za izradu novog nastavnog plana značajna je bila i Radionica inicirana potrebom da se $u$ polju bibliotečke i informacijske znanosti (Library and Information Science, LIS), unutar različitih organizacijskih modela koji nude raznovrsne modele i smjerove, utvrde jezgreni sadržaji koji predstavljaju temelj studija LIS-a. ${ }^{48}$

Naredna revizija NPP urađena je ak. 2013./14. godine, s napomenom da se prema bolonjskom procesu studiranja bibliotekarstvo može studirati kao dvopredmetni studij na matičnom odsjeku (Odsjek za komparativnu književnost i bibliotekarstvo), i u kombinaciji sa drugim studijskim grupama Filozofskog fakulteta. ${ }^{49}$

Najveće promjene donosi NPP iz 2019./20. godine. Studijski program informacijskih nauka, smjer bibliotekarstvo, donosi nove i izmijenjene predmete, na I. i II.

\footnotetext{
48 Nastavni planovi i programi Odsjeka za komparativnu književnost i bibliotekarstvo od akademske 2008./09. dostupni su na https://www.ff.unsa.ba/files/trajno/npp/komparativna_bibliotekarstvo/Akademska_2008_09.pdf. [citirano: 2021-02-06].

${ }^{49}$ Usp. Dizdar, S. Obrazovanje bibliotekara za društvo znanja. // XXII. Proljetna škola školskih knjižničara Republike Hrvatske. Školska knjižnica i slobodno vrijeme učenika: Zbornik radova. / uredila B. Šušnjić. Zagreb: Agencija za odgoj i obrazovanje, 2010. Str. 81-91. Također vidi: Dizdar, S. Bolonjski proces i studij bibliotekarstva. // II savjetovanje visokog obrazovanja - Primjena Bolonjskih principa na Univerzitetu u Sarajevu. Sarajevo: Univerzitet, 2008. Str. 261-270; Dizdar, S. Edukacija bibliotekara: Prilagođavanje tradicionalnih programa «novom vremenu». // ICSL Godišnjak međunarodnog susreta bibliotekara. Sarajevo. 3, 3(2007), str. 31-45.
} 
ciklusu studija, kao i povećan broj sati prakse, kako na matičnom dvopredmetnom studiju, tako i na dvopredmetnim studijskim programima bibliotekarstva i druge studijske grupe. Pokušaj da se obrazovanje bibliotekara harmonizira sa svjetskim praksama te da Katedra preraste u Odsjek još uvijek nije realiziran, ali kao prelazna faza, a koja korespondira i sa novim NPP-om iz 2020. godine Odsjek za komparativnu književnost i bibliotekarstvo je preimenovan u Odsjek za komparativnu književnost i informacijske nauke, odnosno Katedra za bibliotekarstvo u Katedru za informacijske nauke, pri čemu će diplome još uvijek odslikavati realnu formalnu izobrazbu. Za prvostupnika to će biti bakalaureat informacijskih znanosti/ bibliotekarstva, a za Drugi ciklus magistar informacijskih nauka/ bibliotekarstva.

Kada je kontinuitet obrazovanja bibliotekara na sva tri ciklusa studija na Odsjeku u pitanju, valja naglasiti da je Odsjek 2020. godine pripremio Prijedlog doktorskog studija iz informacijskih nauka, Elaborat sa Nastavnim planom i programom, u skladu sa važećim Pravilima studiranja za treći ciklus studija na Univerzitetu u Sarajevu, te isti uputio u daljnju proceduru.

Od njegova osnivanja do februara 2021. godine na Odsjeku za komparativnu književnost i informacijske nauke, diplomiralo je ukupno 483 studenata bibliotekarstva po predbolonjskom režimu studija, te ukupno 245 studenata bibliotekarstva po bolonjskom režimu studija, i to 185 na I. ciklusu studija, te 60 na II. ciklusu studija.

\subsection{Obrazovanje bibliotekara u Istočnom Sarajevu i Mostaru}

Uz obrazovanje bibliotekara na Filozofskom fakultetu u Sarajevu, u poslijeratnom periodu pokrenuti su novi studiji bibliotekarstva, i to Odsjek za opštu književnost i bibliotekarstvo na Filozofskom Fakultetu u Istočnom Sarajevu, te Odsjek za informacijske znanosti na Filozofskom fakultetu Sveučilišta u Mostaru,

Odlaskom profesora sa Katedre bibliotekarstva sa Filozofskog fakulteta u Sarajevu stvorena je kadrovska pretpostavka da se i na novoformiranom Filozofskom fakultetu u Istočnom Sarajevu u Republici Srpskoj osnuje Katedra za bibliotekarstvo na Odsjeku za opštu književnost i bibliotekarstvo. Odsjek je osnovan akademske 1997./98. godine sa ciljem razvoja bibliotekarstva u Republici Srpskoj, ali i da se obezbijedi mogućnost dovršetka studija i magistarskih radova prijeratnim studentima sa Filozofskog fakulteta u Sarajevu. ${ }^{50}$ Reformiranje studija u skladu sa Bolonjskim procesom pokrenuto je i na i Odsjeku za opštu književnost

50 Maksimović, M. Tradicionalni i novi zadaci današnjih bibliotekara. // Bibliotekarstvo Srpske 2, 2(2010), str. 7-8. Također, prvi magistarski rad na Katedri za opštu književnost i bibliotekarstvo Filozofskog fakulteta Univerziteta u Istočnom Sarajevu odbranjen je 1999. godine, a prva doktorska disertacija iz bibliotečkih nauka na tom Fakultetu odbranjena je 2000. godine. Vidi: Istorijat Katedre za bibliotekarstvo. [citirano: 2021-03-11]. Dostupno na: https://ff.ues.rs.ba/istorijat-katedre-za-bibliotekarstvo. 
i bibliotekarstvo 2007. godine i predložen je novi nastavni plan u kome je studij bibliotekarstva i dalje ostao dvopredmetan, a nastava se organizira po principu četverogodišnjeg studija sa petom godinom master studija i doktorskim studijama.

Osnivanjem Društva bibliotekara Republike Srpske 1997. godine u Višegradu i donošenjem Zakona o bibliotečkoj djelatnosti Republike Srpske, Zakona o izmjenama i dopunama Zakona o bibliotečkoj djelatnosti Republike Srpske, Pravilnika o polaganju stručnih ispita zaposlenih u bibliotečkoj djelatnosti stvoreni su uslovi za polaganje stručnih ispita iz bibliotekarstva koji se polažu u Narodnoj i univerzitetskoj biblioteci Republike Srpske. ${ }^{51}$ Prethodno navedeni zakoni unaprijeđeni su Zakonom o bibliotečko-informacijskoj djelatnosti u Republici Srpskoj (Sl. glasnik, br. 44/16) u kome je članom 67. predviđeno da: „1) zaposleni u bibliotečko-informacijskoj djelatnosti su dužni da se stručno usavršavaju; 2) stručno usavršavanje u bibliotečko-informacionoj djelatnosti vrši se u skladu sa programom koji donosi Narodna i univerzitetska biblioteka Republike Srpske.“

Obrazovanje bibliotekara na Filozofskom fakultetu u Mostaru odvija se na Odsjeku za informacijske znanosti, počevši od akademske 2011./12. godine, ${ }^{52}$ bibliotekarstvo je kao diplomski studij osnovano akademske 2014./15. godine. Od samog početka studij je zamišljen kao jednopredmetni i dvopredmetni studij koncipiran na bolonjskom načelu $3+2$. Zajednička jezgra studija bila bi informacijska tehnologija i nekoliko predmeta vezanih uz zajedničku teoriju informacijske znanosti, baze podataka, obradu građe, obradu jezika i zaštitu građe. Filozofski fakultet Sveučilišta u Mostaru predlaže jedan preddiplomski studij i jedan diplomski studij sa više smjerova (bibliotekarstvo - jednopredmetni i dvopredmetni studij, informatika - istraživački jednopredmetni studij i informatologija - nastavnički dvopredmetni studij). U novom NPP-u iz 2018. godine navodi se: „da ovisno od zainteresiranosti moguće je pokrenuti i smjerove arhivistika i muzeologija i upravljanje baštinom koji se izvode na referentnom studiju tj. Odsjeku informacijskih

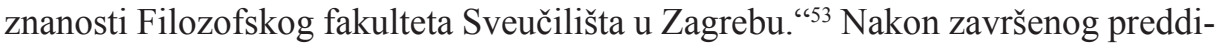
plomskog studija student ima titulu prvostupnika/ce iz informacijskih znanosti ili baccalaureus/baccalaurea, a nakon završenog diplomskog studija titulu magistra/ magistrice određene struke (bibliotekarstva, informacijskih znanosti ili informatologije).

51 Zakon o bibliotečkoj djelatnosti Republike Srpske. // Službeni glasnik Republike Srpske, br. 52/01; Zakon o izmjenama i dopunama Zakona o bibliotečkoj djelatnosti Republike Srpske. // Službeni glasnik Republike Srpske 112/08); Pravilnik o polaganju stručnih ispita zaposlenih u bibliotečkoj djelatnosti. // Službeni list RS br.17/96. Više o tome vidi u: Informacije i termini o stručnom ispitu u JU Narodna i univerzitetska biblioteka Republike Srpske. [citirano: 2020-0925]. Dostupno na: http://nub.rs/info/za-bibliotekare/obrazovanje-bibliotekara.

52 O fakultetu. Mostar: Sveučilište, Filozofski fakultet. [2021-05-15]. Dostupno na: https://ff.sum.ba/hr/stranice/o-fakultetu.

53 Nastavni plan i program prediplomskog i diplomskog studija informacijskih znanosti. Mostar: Filozofski fakultet Sveučilišta u Mostaru, 2018. Str. 5. 


\subsection{Stručni ispiti}

Polaganje stručnih ispita iz bibliotekarstva je jedan od formalnih oblika obrazovanja, jer se njime stiču kompetencije za profesionalni život i rad. Mada to nije obrazovna vertikala uobičajenog sticanja znanja propisana od nadležnih ministarstava, ona je dugo bila jedini oblik stručnog usavršavanja bibliotekara, što se pominje u Biltenu iz 1955. godine..$^{54}$ Taj trend obrazovanja bibliotekara bio je zastupljen sve do 1978. godine kada je Zakonom o bibliotečkoj djelatnosti ukinut.

Ipak, taj oblik obrazovanja bibliotekara u postdejtonskoj Bosni i Hercegovini ponovo je pokrenut u sklopu Permanentnog obrazovanja u Federaciji i provodi ga Nacionalna i Univerzitetska biblioteka Bosne i Hercegovine. Kao prvi oblici obuke, održan je seminar novembra 1997. godine u Tuzli, a sljedeći u Zenici. ${ }^{55}$ Cilj tih poslijeratnih tečajeva je bio da se unaprijedi rad bibliotečkog osoblja koje je bilo skoro u potpunosti izmijenjeno, jer je došlo do priljeva kadrova bez stručne naobrazbe i iskustva, a profesionalni zahtjevi su bili veoma složeni. Već naredne godine 1999. godine, održan je širi kurs kao priprema za polaganje stručnih ispita, koji se po prvi put nakon rata održavaju u junu te godine. ${ }^{56} \mathrm{U}$ Nacionalnoj i Univerzitetskoj Biblioteci Bosne i Hercegovine djeluje i Centar za permanentno obrazovanje bibliotekara, kao jedan od osamnaest srodnih centara Jugostočne Evrope. Centar je otvoren uz podršku Otvorenog društva iz Budimpešte. Centar je svoj strateški razvoj vezao za cjeloživotno učenje što se pokazalo dobrim potezom za uspješno osposobljavanje tehnički i informatički zaostalog kadra, kako navodi Rešidbegović. ${ }^{57}$

U Republici Srpskoj stručni ispit se polaže u Narodnoj i univerzitetskoj biblioteci (Banja Luka) prema Pravilniku i programu stručnog ispita u bibliotečkoj djelatnosti i načinu njegovog polaganja od 2010. godine. ${ }^{58}$

\section{Zaključak}

Razvoj formalnog obrazovanja bibliotekara u Bosni i Hercegovini, rezultat je specifičnih i kompleksnih historijskih i društveno-ekonomskih prilika, usljed kojih je formalno obrazovanje bibliotekara u BiH kaskalo za osnivanjem prvih

\footnotetext{
54 Bibliotekari i knjižničari sa položenim stručnim ispitom. // Bilten Društvo bibliotekara BiH, Narodna biblioteke NR BiH 1, 1(1955), str. 25-26.

55 Usp. Rešidbegović, A. Nacionalna i Univerzitetska biblioteka Bosne i Hercegovine u misiji obrazovanja stručnih kadrova. Sarajevo: Nacionalna i Univerzitetska biblioteka Bosne i Hercegovine, 2014. Str. 93.

56 Usp. Isto, str. 93.

57 Isto, str. 94.

58 Pravilnik i program stručnog ispita u bibliotečkoj djelatnosti i načinu njegovog polaganja od 2010. godine. // Službeni glasnik Republike srpske 10/03(2021) [citirano: 2021-05-11]. Dostupno na: https://nub.rs/info/za-bibliotekare/obrazovanje-bibliotekara.
} 
bibliotečkih škola, primjerice u SAD-u (1887. godina). Osmanski period, zatim austrougarski period, a koji je najmanje istražen u postojećoj literaturi, period bivše Jugoslavije, te postdejtonski period, značajno su i različito utjecali na razvoj bibliotekarstva u BiH.

Osmanski period u Bosni i Hercegovini obilježilo je osnivanje prvih biblioteka, među kojima Gazi Husrev-begova biblioteka u kontinuitetu djeluje i danas. Najbogatije biblioteke Osmanskog perioda bile su islamske vakufske biblioteke i djelovale su u statusu javnog dobra. Prve veće zbirke knjiga vezane su uz vjerske i vjersko-obrazovne ustanove, uz džamije, tekije i medrese, te uz crkve, samostane, manastire i vjerske škole, što je praksa koja je dominirala do 19 st., paralelno sa privatnim sakupljanjem (sabiranjem) zbirki. Do perioda između dva svjetska rata, biblioteke su postojale u okviru kulturno-prosvjetnih društava i sličnih institucija, uglavnom sa relativno malim fondom. Vrijeme nakon Drugog svjetskog rata dinamičan je period bosanskohercegovačkog bibliotekarstva kada se uspostavlja mreža narodnih, školskih, visokoškolskih i specijalnih biblioteka, uz Narodnu biblioteku SR Bosne i Hercegovine iz 1945., koja prerasta u Narodnu i univerzitetsku biblioteku 1975. godine. U tom periodu započinje i profesionalizacija bibliotečke djelatnosti uspostavljanjem zakonskih i obrazovnih okvira profesije.

Kao ključnu prekretnicu za formalno obrazovanje bibliotekara u bosanskohercegovačkom prostoru treba izdvojiti 1972. godinu, kada je na Filozofskom fakultetu u Sarajevu osnovan Odsjek za opštu književnost, scenske umjetnosti i bibliotekarstvo. Nastavni planovi i programi Katedre za bibliotekarstvo, koja je 2020. godine preimenovana u Katedru za informacijske nauke, tokom 49 godina kontinuiranog postojanja Katedre, nastojali su pratiti promjene u oblasti bibliotečko-informacijskih nauka, a u vrlo kompleksnim i zahtjevnim bosanskohercegovačkim okolnostima. Kada su perspektive budućeg razvoja obrazovanja bibliotekara na Katedri u pitanju, razumno je u nadolazećem periodu očekivati proaktivno revidiranje nastavnih planova i programa, a koji će pratiti međunarodne trendove odnosno akademske standarde u pogledu formalnog obrazovanja informacijskih stručnjaka.

\section{LITERATURA}

Bakaršić, K. Fragmenti kulturne historije Bosne i Hercegovine. Sarajevo Magistrat, 2005.

Bašeskija, M. M. Ljetopis. Sarajevo: Sarajevo-Publishing, 1997.

Bašović, Lj. Biblioteke i bibliotekarstvo u Bosni i Hercegovini 1918-1945. Sarajevo: Veselin Masleša, 1986. 
Bašović, Lj. Prilog proučavanju problematike nastavnog plana i programa studija iz oblasti bibliotekarstva. // Bibliotekarstvo 20, 1(1974), 23-33.

Bašović, Lj. Biblioteke i bibliotekarstvo u Bosni i Hercegovini 1945-1975. Sarajevo: Svjetlost, 1977.

Bibliografija Biltena Društva bibliotekara BiH i Narodne biblioteke NR BiH i časopisa Bibliotekarstvo: 1952-2001 / izradile N. Grebović-Lendo i suradnici. Sarajevo: Društvo bibliotekara Federacije Bosne i Hercegovine, 2016.

Bibliotekari i knjižničari sa položenim stručnim ispitom. // Bilten Društvo bibliotekara BiH, Narodna biblioteke NR BiH 1, 1 (1955), str. 25-16.

Čaki, P. Predlog sistema školovanja bibliotečkih radnika u SFRJ. // Bibliotekarstvo 24, 1/2 (1978), 55-66.

Čeliković, S. Biblioteke i bibliotekarstvo u Bosni i Hercegovini od 1975. do 2010. godine: Doktorska disertacija. Sarajevo: Filozofski fakultet, 2017.

Čeliković, S. Biblioteke i bibliotekarstvo u Bosni i Hercegovini od 1975. do 2010. godine. Tešanj: Planjax komerc, 2019.

Čeliković, S. Islamske biblioteke u Bosni i Hercegovini 1878-2010. Tuzla: Specijalna biblioteka „Behram-beg“, 2014.

Dizdar, S. Obrazovanje bibliotekara za društvo znanja. // XXII. Proljetna škola školskih knjižničara Republike Hrvatske. Školska knjižnica i slobodno vrijeme učenika: zbornik radova / ur. Biserka Šušnjić. Zagreb: Agencija za odgoj i obrazovanje, 2010. Str. 81-91.

Dizdar, S. Bolonjski proces i studij bibliotekarstva. // II savjetovanje visokog obrazovanja -Primjena Bolonjskih principa na Univerzitetu u Sarajevu. Sarajevo: Univerzitet, 2008. Str. 261-270.

Dizdar, S. Edukacija bibliotekara: Prilagođavanje tradicionalnih programa «novom vremenu» i promijenjenom vremenu. // ICSL Godišnjak međunarodnog susreta bibliotekara slavista u Sarajevu 3, 3(2007), 31-45.

Erl Šafar, M.; T. Lubina. Formalno obrazovanje knjižničara: Kratki povijesni pregled. // Vjesnik bibliotekara Hrvatske 61, 1(2018), 219-239.

Fajić, Z. Biblioteka Abdullah efendije Kantamirije. // Anali Gazi Husrev-Begove Biblioteke, 8(1987), 13-36. [citirano: 2021-04-18]. Dostupno na:

https://anali-ghb.com/index.php/aghb/article/view/502.

Filan, K. Sarajevo u Bašeskijino doba. Sarajevo: Connectum, 2014.

Gašparović, Z. Problemi školovanja bibliotečkih kadrova // Bibliotekarstvo, 1(1962), $1-10$.

Hadžiosmanović, L. Biblioteke u Bosni i Hercegovini 1878-1918. Sarajevo: Veselin Masleša, 1980. 
Horvat, A. Školovanje knjižničara u svjetlu europskih normi. // Vjesnik bibliotekara Hrvatske 48, 1(2005), 1-12.

Informacije i termini o stručnom ispitu u JU Narodna i univerzitetska biblioteka Republike Srpske, 2019. godine. [citirano: 2020-09-25]. Dostupno na: http://nub.rs/info/za-bibliotekare/obrazovanje-bibliotekara.

Istorijat Katedre za bibliotekarstvo. [citirano: 2021-03-11] Dostupno na: https://ff.ues. rs.ba/istorijat-katedre-za-bibliotekarstvo.

Kaleder, F. Radničke biblioteke i čitaonice u Bosni i Hercegovini do 1941. godine. Sarajevo: Društvo bibliotekara Bosne i Hercegovine, 1998.

Lalević, O.; Dautović, A. Biblioteka Zemaljskog muzeja Bosne i Herceovine do 1897. godine // Informatica museologica, 29, 1/2 (1998), 73-75.

Lavić, O. Bibioteke u Bosni i Hercegovini za vrijeme osmanske uprave: Magistarski rad. Sarajevo: Fakultet islamskih nauka Univerziteta u Sarajevu, 2013.

Leota, A. Kadrovi u bibliotečko-informacionoj djelatnosti Bosne i Hercegovine i njihov obrazovanje. // Bibliotekarstvo 34(1988), 16-19.

Maksimović, M. Tradicionalni i novi zadaci današnjih bibliotekara. // Bibliotekarstvo Republike Srpske 2, 2(2010), 3-14.

Memija, E. Od slike do knjige: Iz historije pisma, knjige, štampe i biblioteke. Sarajevo: Nacionalna i univerzitetska biblioteka BiH, 2007.

Mihaliček, M. Školovanje knjižničara u Bosni i Hercegovini. // Bibliotekarstvo 34(1987), 46-49.

Mihaliček, M. Obrazovanje knjižničara u školama srednjeg usmjerenog obrazovanja u Bosni i Hercegovini. // Bibliotekarstvo 34(1982), 99-101.

Mujezinović, M., Traljić, M. Vakufnama iz 1630. godine o osnivanju biblioteke Mevla Husamuddina Bošnjaka u Banjoj Luci. // Glasnik islamske vjerske zajednice 40, 1(1977), 28-39.

Nacionalna i univerzitetska biblioteka Bosne i Hercegovine: 1945 - 2005: 60 godina u misiji kulture, obrazovanja i nauke. Sarajevo: NUBBiH, 2005.

Nastavni plan i program iz bibliotekarstva. Sarajevo: Filozofski fakultet u Sarajevu, Odsjek za opštu književnost i bibliotekarstvo, 1985.

Nastavni plan i program preddiplomskog i diplomskog studija informacijskih znanosti. Mostar: Flozofski fakultet Sveučilišta u Mostaru, 2018.

Nastavni plan i program postdiplomskog studija iz bibliotekarstva: Akademska 2007/2008. godina. Sarajevo: Filozofski fakultet u Sarajevu, 2008.

Nastavni plan i program Odsjeka za komparativnu književnost i bibliotekarstvo ak. 2008/09. [citirano: 2021-02-06]. Dostupno na: https:/www.ff.unsa.ba/files/trajno/ npp/komparativna_bibliotekarstvo/Akademska_2008_09.pdf. 
Nastavni plan i program sa režimom studija. Sarajevo: Filozofski fakultet. Odsjek za opštu književnost i bibliotekarstvo, 1973.

Nastavni plan i program. Sarajevo: Filozofski fakultet. Odsjek za opštu književnost i bibliotekarstvo, 1990.

Nomenklature zanimanja. Sarajevo: Privredna komora BiH, 1980.

O fakultetu. Mostar: Sveučilište, Filozofski fakultet. [citirano: 2021-05-15]. Dostupno na: https://ff.sum.ba/hr/stranice/o-fakultetu.

Okvirni zakon o visokom obrazovanju. // Službeni glasnik BiH, br 59/07). [citirano: 2021-01-10]. Dostupno na: http://fmpe.edu.ba/images/pdf/101_Okvirni_zakon_o_ visokom_obrazovanju_u_Bosni_i_Hercegovini.pdf

Papić, M. Školstvo u BiH u vrijeme austrougarske okupacije (1878-1918). Sarajevo: Veselin Masleša, 1972.

Pejanović, Đ. Kratka uputstva za osnivanje, uređenje i rukovanje narodnih javnih knjižnica. Sarajevo: Društvo prosvjeta, 1920.

Pravilnik i program stručnog ispita u bibliotečkoj djelatnosti i načinu njegovog polaganja od 2010. godine. // Službeni glasnik Republike Srpske, br. 10/03, 2021. [citirano: 2021-05-11].Dostupno na: https://nub.rs/info/za-bibliotekare/obrazovanje-bibliotekara.

Pravilnik o polaganju stručnih ispita zaposlenih u bibliotečkoj djelatnosti. // Službeni list Republike Srpske br. 17/96.

Postiplomski studij iz bibliotekarstva „Inovacije u bibliotekarstvu“. Sarajevo, Filozofski fakultet, Odsjek za opštu književnost i bibliotekarstvo, 1985.

Radulović, Z. Dr Ljubinka Bašović: Bibliotekar i pedagog novog doba. // Glasnik Narodne biblioteke Srbije 4, 1(2002), 11-36.

Rašidović, B. E. Cjeloživotno učenje informacijskih stručnjaka/bibliotekara i informacijska pismenost. // Proaktivne obrazovne institucije - mjesto cjeloživotnog učenja u digitalnom dobu: Zbornik radova. / uredile S. Dizdar, A. Rešidbegović i B. Sabljaković. Sarajevo: Asocijacija informacijskih stručnjaka - bibliotekara, arhivista i muzeologa, 2015. Str. 45-52. Dostupno na: http://bam.ba/images/stories/Zbornici/ zbornik13.pdf.

Rašidović, B. E. Bibliotekari/ke osobe bez identiteta?: Zašto vjerujete svom pekaru, mljekaru, apotekaru a ne vjerujete svom bibliotekaru? // ur. vijeće R. Donia et. al. Sarajevo: Fondacija "Kemal Bakaršić”; University Press, 6/7, (2011), 9-17.

Rešidbegović, A. Nacionalna i univerzitetska biblioteka Bosne i Hercegovine u misiji obrazovanja stručnih kadrova. Sarajevo: Nacionalna i Univerzitetska biblioteka Bosne i Hercegovine, 2014.

Schematismus almae Missionariae provinciae Bosnae Argentinae ordinis fratrum Minorum observantium: pro anno 1864. Budae: Typis Martini Bagô, 1864. 
Švenda-Radeljak, K. Obrazovanje i status knjižničara u Hrvatskoj do uvođenja studija bibliotekarstva. Zagreb: Pravni fakultet, 2018.

Švenda-Radeljak, K. Počeci razvoja knjižnične profesije u Hrvatskoj od 1875-1918. godine. Zagreb: Pravni fakultet, 2018.

Zakon o visokom obrazovanju. // Sl. glasnik Republike Srpske, br. 73/2010, 104/2011, 84/2012, 108/2013, 44/2015, 90/2016, 5/2017 - odluka US, 31/2018 i 26/2019. [citirano: 2021-01-10]. Dostupno na: https://www.paragraf.ba/propisi/republika-srpska/zakon-o-visokom-obrazovanju.html.

Zakon o bibliotečkoj djelatnosti R BiH. // Službeni list R BiH, br. 37/95.

Zakon o bibliotečkoj djelatnosti SR BiH. // Službeni list SR BiH 26/86.

Zakon o bibliotečko informacionoj djelatnosti. // Službeni glasnik Republike srpske 2016. br. 44, god. XXV). [citirano: 2021-01-10]. Dostupno na:

http://nub.rs/fileadmin/user_upload/Zakon-o-bibliotečkoj-delatnosti.pdf.

Zakon o bibliotečkoj djelatnosti Republike Srpske. // Službeni glasnik Republike Srpske, br. 52/01.

Zakon o izmjenama i dopunama Zakona o bibliotečkoj djelatnosti Republike Srpske. // Službeni glasnik Republike Srpske 112/08.

Ždralović, M. Bosansko-hercegovački prepisivači djela u arabičkim rukopisima, Knj. I. Sarajevo: Svjetlost, 1988. 